mass murderers and downright repulsive figures have dominated so much of history since the 1960 s is at least as unpleasant as DeGroot imagines and, in this reviewer's opinion, a great deal worse. Ecology is only a passing thought in The Sixties Unplugged, but he stops long enough to say that corporations supply consumer goods, so any attempt to blame them must have been misguided! Thereby, he misses the eco-logic aspects of the decade along with the defeat, however temporary, of Empire as dominant principle in the globe. More importantly, DeGroot misses the pulsating beat of the mass movements themselves, which by seeking to supersede corporate rule and the limits of representative democracy with forms of direct democracy, helped develop the kind of world upon which Dr. King insisted was reachable.

What remains of the 1960 s as a glamorous, rebellious era? The sense that an institutional and militarized society dependent upon the vision of a permanent enemy is not invincible. And that global democracy, repudiating the redirection of natural resources and local economies by neo-colonialism away from the hopes of early independence days into corporate ledgers, can still happen. These are ideas so simple, so revolutionary, that practically anyone can grasp them and the urgent need for them if we are to survive. Not, of course, our Professor DeGroot.

Paul Buhle

Brown University

Linda Eisenmann, Higher Eduation for Women in Post-war America, 19451965 (Baltimore: The John's Hopkins University Press 2006), and Andrew Hartman, Education and the Cold War: The Battle for the American School (New York: Palgrave MacMillan, 2008).

The Cold War era continues to fascinate North American academics and two recent studies by US historians explore complementary aspects of educational change in this period. Linda Eisenmann focuses on a coterie of female reformers who sought to expand post-secondary educational opportunities for women in the twenty years following World War II, and Andrew Hartman takes up the "battle for the American school" among progressive educators, political activists and anticommunists during the same era. While the two books, written from very different perspectives, do not uncover much that is new in the history of education, they raise interesting historiographical and methodological questions that future students of this period (and others) would be wise to consider.

Eisenmann seeks to recapture and acknowledge the work of liberal reformers, those middle class professionals who contributed to educational and social change without ever eliciting the acclaim and notoriety of Betty Friedan, author of the extraordinarily influential, The Feminine Mystique (1963) and the feminist activists who followed in her wake. She provides case studies of several 
organizations: The American Council on Education Commission on the Education of Women, the American Association of University Women, the National Association of Deans of Women, and the President's (Kennedy) Commission on the Status of Women. She also examines women's continuing education initiatives in several American universities during the 1950s and 60s.

None of the leaders of these associations could be considered radical; indeed most would have eschewed the label "feminist". They understood that women in the post war period (including themselves) were enveloped by the home and hearth mythology that pervaded post-war America. The iconic housewife nurtured her children and husband, engaged in volunteer work, and, if she had time, pursued educational and other pursuits. The nuclear family was perceived as the social bedrock of the nuclear age.

In reality, women were increasingly working and pursuing post-secondary education. The participation rate of married women in the American labour force rose from 22 to 31 per cent between 1950 and 1960, and organizations such as the American Association of University Women sought to smooth the path from home to work for career-oriented women. Their advocacy was "adaptive," incrementalist and focused on individuals not collectivities. The pursuit of full gender equality appeared neither possible, nor for some reformers, advisable. The author suggests that, like the previous generation of material feminists, they attempted to secure recognition for women's distinctive social sphere, and then expand its boundaries in ways that served female aspirations and interests.

Perhaps their most noteworthy accomplishment was the establishment of path-breaking continuing education programs for women at four American universities. While falling off the radar during the student uprisings of the late $1960 \mathrm{~s}$, such programs, which addressed the needs of part-time, mature, and married students, were replicated in later decades. The President's Commission on the Status of Women promoted better child care standards and tax deductions for families with children in day care, and the American Association of University Women, consisting of alumni from liberal arts colleges, provided an important network for the discussion of social issues.

But as the author also notes, two important issues that the middle class liberal reformers largely avoided were race and class. They confronted neither the particular challenges of working class women, nor the systemic racism in education, including in some of their own organizations. The latter issue was politically explosive, and the reformers' relentless respectability left them with little to say, at least until the civil rights movement took hold.

This is a meticulously researched, though exceedingly repetitive study. The author bends over backwards to place the concerns of her subjects in historical perspective, which is why, in the end, she finds reason to praise their labours. The Cold War era was especially hostile to the kind of radical activism that erupted in the late 1960s, and the efforts of reformers, including those with "limited" 
vision and aspirations, merit serious historical attention, which they certainly receive in this book.

As a self-described Marxist scholar, Andrew Hartman would undoubtedly be dismissive of Eisenmann's cast of politically moderate players. This book traces the journey and fate of advocates both of progressive education and more radical versions of educational change. In short, virtually all of these individuals either suffered ideological repression or betrayed the cause of enlightened, democratic education. In his original writings on education and philosophy, educational philosopher John Dewey, according to the author, provided the framework for genuinely progressive schooling, but the conservatism of many of his supposed followe rs, in combination with rampant red-baiting which spanned several decades, derailed the grand plan.

Indeed, apart from the young John Dewey, Theodore Brameld, a radical utopian educational theorist, and Willard Goslin, a Pasadena education superintendent who attempted in vain to desegregate the city's schools, this study is dominated by intellectual villains. Ex-communists turned anti-communist, George Counts and Bella Dodd; historian Richard Hofsteadter; educators James Bryant Conant and Robert Hutchins, among others, all apparently played a role in marginalizing both radical thinking and genuinely progressive educational policy.

The latter point, however, is merely speculative. One of the major weaknesses of this book is its failure to explore what actually happened in American classrooms before and during the Cold War. Like some of the commentators he cites, the author asserts but does not demonstrate that progressivism, or at least some version of it, was the dominant pedagogical paradigm in American schools of the 1930s and 40s. (This is a source of continuing historiographical controversy, creatively addressed in Ronald Cohen's, Children of the Mill: Schooling and Society in Gary Indiana, 1911 to 1961, which does not appear in Hartman's bibliography). Some of the author's statements are sweeping and stunning in their simplicity. "Whereas most administrators once thought of themselves as schoolmasters dedicated to enhancing the liberal curriculum, by mid-century most considered their work akin to running a business. Their primary duty was to tailor their young charges to fit the economic order"(62). The world of American schooling was far more complicated than this assertion implies.

Unlike Eisenmann's study which is drawn from original sources, Hartman's is derived almost entirely from secondary writings and the events he chronicles, particularly the anti-communist educational purges, will be familiar to readers of modern American educational history. Nor with its turgid, complex prose, will his volume reach a broader non-academic audience. And even within academia, both of these books are likely to have a limited readership, Eisenmann's because of its highly specialized focus and Hartman's because of its ideological heavy-handedness. 
A final historiographical question provoked by both books: is it possible for historians of social activism to avoid the heroic (or anti-heroic) treatment of their subjects? Do there always have to be retrospective political winners and losers? And shouldn't historians (whatever their political biases) serve as investigators, narrators, and storytellers of lives and times rather than as moralists and judges? These questions are not entirely rhetorical.

Paul Axelrod

York University

\section{Laura Hapke, Labor's Canvas: American Working-Class History and the WPA Art of the 1930s (Newcastle, UK: Cambridge Scholars Publishing, 2008).}

In the triumvirate of New Deal-sponsored cultural initiatives, several studies have examined the Federal Writers' Project and the Federal Theater Project; however, a comprehensive survey of the third artistic component of the WPA, the Federal Art Project (FAP), has been largely absent. Fortunately, there is now Laura Hapke's Labor's Canvas. For over two decades, Hapke has sought to place at centre the lives of labourers so often on the margins of American culture. This is evident in her previous works, such as Labor's Text: The Worker in American Fiction (Rutgers, 2001) and Sweatshop: The History of an American Idea (Rutgers, 2004). Labor's Canvas emerges as a continuation of these studies, seeking to again place value on working-class history and culture. This text, at once an examination of art, history, politics, race, class, and gender, emerges as a seminal work for scholars of history, labour studies, art history, and American Studies.

What is evident from Hapke's study are the diverse and complex nuances that permeated FAP art. Divided into two main parts, Part One, "Male and Pale: Unionism and Art," and Part Two, "Catching the CIO Spirit: The FAP and Multicultural Workers," Labor's Canvas explores the complicated notion of "a WPA artistry both responsive to and ambivalent about labor" (8). This statement makes clear the thorny nature of the job for many WPA artists: "artists saw themselves as cultural workers who had much in common with the blue-collar workforce. Yet artistically, they struggled to reconcile social protest and aesthetic distance" (2). Whether seeking a way to accurately depict the "self in industrial work" or balancing their radical impulses with the aims of a government-subsidized arts program, artists found themselves in complicated and often contradictory positions (9). Yet these intricate political and cultural subtexts, Hapke observes, provide the rich undercurrent of FAP art.

Another important focus of Hapke's project, made especially apparent in Part Two, is the attention given to diversity and multiculturalism in WPA art. Many 